\title{
PHYSICIANS AT THE OTTOMAN COURT
}

\author{
by
}

\section{G. A. RUSSELL *}

\section{INTRODUCTION: A "MONDE RENVERSE"}

Between its foundation by Sultan Mehemmed the Conqueror (reg. 1451-81) and its abandonment in the middle of the nineteenth century, the Saray, the Palace in Constantinople, served for more than 400 years not only as the residence of the Ottoman Sultans and their royal household, but also as the seat of their imperial rule. More than that, it determined the imprint of Ottoman society.

The immense enclosure on what is called the Seraglio Point, surrounded by impressive fortifications, consisted of an "outer" Bīrün and an "inner" Enderün section within a series of courtyards. The Bīrün, which included the Dīvān or Imperial Council Chamber, was of necessity partly open to the outside; the Enderün or inner palace, separated by a second line of walls, contained the private apartments of the Sultan, the Imperial Household, the Harem, and the Pavilion of the Holy Mantle, as well as the special Palace School. ${ }^{1}$ Because of the strict privacy beyond what was called the "Gate of Felicity", the inner palace was inaccessible. It was perhaps justifiably referred to by some historians as the "forbidden city".2 As late as 1822 , Joseph von Hammer-Purgstall, Secretary to the Austrian Embassy in Constantinople, and the author of the monumental Geschichte des osmanischen Reiches, could still declare with the utmost confidence that no Europeans except physicians had ever entered it and that no one had ever described it. ${ }^{3}$ Although von Hammer was referring specifically to the Harem, it could have been said for the whole inner palace.

The frustration of the foreigner with the difficulty of ascertaining even matters of no importance is reflected in the comment of Pietro della Valle, writing from Constantinople in 1615: "Those who dwell beyond the third gate, who in their own

*G. A. Russell, Wellcome Institute for the History of Medicine, 183 Euston Road, London NW1 2BN and Dept. of Humanities in Medicine, College of Medicine, Texas A \& M University, College Station TX 77843-1114, USA.

A shorter version of this paper was given at the workshop on "Medicine at the Royal Court", Herzog August Bibliothek, Wolfenbüttel, 1986.

\footnotetext{
${ }^{1}$ For a description of the social and political structure of the palace, see $\mathrm{H}$. Inalcik, 'The Palace', in The Ottoman Empire: the classical age 1300-1600, trans. Norman Itzkowitz and Colin Imber, London, Weidenfeld \& Nicolson, 1972; pp. 78-88. Also, I. H. Uzunçarşıll, Osmanl l Devletinin Saray Teşkilatı, Ankara, 1945, based on Ottoman archival sources.

2 Barnette Miller, Beyond the Sublime Porte: the Grand Seraglio of Stambul, New Haven, Yale University Press, 1931, repr. 1970, pp. 3-21.

${ }^{3}$ Joseph von Hammer-Purgstall, Constantinopolis und der Bosporos, Pest, 1822, vol. 1, p. 267; in Miller, op. cit., note 2 above, p. 11 .
} 


\section{G. A. Russell}

person see or serve the Grand Seignor, live as he does, removed from all contact with the outside world; and for that reason it happens that one learns so little of the truth of the affairs of this Court...". Any attempt to pierce the royal privacy proved costly, as in the case of the Venetian dragoman Signor Grellot, who was put to death for having gazed at the Palace through a telescope from the window of his dwelling in Pera. ${ }^{5}$ The frequency with which this incident, whether authentic or not, was cited serves to illustrate the fact that the inner palace was a closed world.

Designated in the West as the "grand seraglio", the "sublime porte" and, during the period of its decline from the seventeenth century onwards when it was no longer sublime, merely as the "porte", the Ottoman court remained impenetrable. Surrounded by secrecy, it could on occasion be surreptitiously glimpsed through the rare accounts of former pages, travellers, diplomatic envoys, and others. ${ }^{6}$ The only foreigners who were privileged enough to be admitted were indeed physicians, either attached to the court or summoned in exceptional circumstances from the outside and even allowed to go into the Harem between two heavily packed rows of black eunuchs! In fact, one of the earliest extant accounts is by an Italian physician at the court of Murād III (1574-95), Domenico Hierosolimitano, in his Relatione della gran citta di Constantinopoli of 1611 . He was apparently one of seven physicians and third in the order of seniority in attendance to the Sultan. ${ }^{7}$

The paucity of direct information and the inaccessibility of the Court seem to have been in inverse proportion to the frequency of descriptions. ${ }^{8}$ In some of the accounts, there were attempts to analyse the nature of the Ottoman court in order to understand the secret of Ottoman military power and show what were seen, by contrast, as the weaknesses of the European society and governments, as in the well-known letters of Ogier Ghiselin de Busbecq, the Flemish ambassador of the Habsburgs between 1554 and $1562 . .^{9}$ Other accounts were less complimentary. Paul

\footnotetext{
4 Viaggi di Pietro della Valle ... divisi in tre parti, ciò̀ la Turchia, la Persia, e l'India, Rome, 1650; transl. into French by E. Carneau and F. Le Comte as Les fameux voyages de Pietro della Valle ..., Paris, 1662-5. An English translation of the relevant passage is in Miller, op. cit., note 2 above, p. 5.

${ }^{5}$ François Pétis de la Croix, Etat général de l'Empire Ottoman, Paris, 1695, vol. 1, p. 355; Corneille Le Bruyn, Voyage au Levant, Pais, 1725, vol. 1, p. 141; in Miller, op. cit., note 2 above, p. 5.

${ }^{6}$ Saray in Ottoman sources refers to the Palace. In European sources, serraglio or seraglio came to refer to the private apartments of women. An interesting explanation is given for this specific usage, deriving from the combination of the chance resemblance of the Italian serraglio, i.e., a cage for wild animals(!), and the Persian saray, which originally meant a "building", particularly a "place"; see N. M. Panzer, The Harem, London, 1936, repr. 1967, pp. 15-16. The term for women's quarters in Ottoman Turkish was harem (and haremlik) which comes from the Arabic haram in the legal sense of that which is not permitted or allowed; inviolate, sacred.

${ }^{7}$ London, British Library, Ms. Harley 3408, fols. 83-141. His appointment was probably due to the influence of the Sultan's wife Săfiya (Panzer, op. cit., note 6 above, pp. 186-7), rather than that of the Sultan's mother, Nūr Bānū (Miller, op. cit., note 2 above, p. 167), who died in 1583. Because of the partiality shown by both ladies to the Republic of Venice, their identities have been confused. The Venetian Cecilia Venier-Baffo was the Sultan's mother, not his wife, as Panzer erroneously states.

${ }^{8}$ C. D. Rouillard, The Turk in French history, thought, and literature 1520-1660, Études de littérature étrangère et comparée 13, Paris, 1936, esp. part 3.

${ }^{9}$ Originally published as Legationis turcicae episolae quatuor, Paris, 1589. For its English editions, see The four epistles of A. G. Busbequius concerning his embassy, London, 1694; C. E. Forster and F. H. B. Daniell, The life and letters of Ogier Ghiselin de Busbecq, 2 vols., London, Kegan Paul, 1881; Turkish letters of Ogier Ghiselin de Busbecq ... translated from the Elzevir edition of 1633 by Edward Seymour Forster, Oxford, Clarendon Press, 1921.
} 


\section{Physicians at the Ottoman Court}

Rycaut, who was in Instanbul between 1661 and 1667, regarded "the whole composition of the Turkish Court" as "a prison and banniard of slaves, differing from that where the galley slaves are immured only by the ornaments and glittering outside". ${ }^{10}$

Edward Gibbon in the eighteenth century perhaps came nearer the truth when he wrote: "In the vigorous age of the Ottoman government, the Turks were themselves excluded from all civil and military honours; and a servile class, an artificial people, was raised by the discipline of education to obey, to conquer, and to command". ${ }^{11}$ Elegantly exaggerated, his comment touched on a most significant aspect of the Ottoman court. What emerged was a world so radically different as to be almost incomprehensible: a monde renversé, where slaves constituted the élite. In fact, the Palace included a unique school designed to provide the training and the education to turn Christian slaves from all walks of life into the Ottoman military and administrative élite.

Gibbon's distinction was taken up at the beginning of the twentieth century by the American historian A. H. Lybyer and developed into a thesis in his The government of the Ottoman Empire in the time of Suleiman the Magnificent, with the catch-labels of the "ruling and the moslem institutions". ${ }^{12}$ This thesis, which credited the success of the Ottomans to the presence of men of Christian origins in positions of importance and the subsequent decline of the empire to their replacement by the Muslim-born, was accepted by historians without question. ${ }^{13}$ Largely based on European sources, it provided a neat distinction of great emotional appeal, attributing a genetic role to religion. Ottoman realities, however, slowly emerging from the Imperial State Archives, seem, in more recent studies, to elude such simple, rigid distinctions or absolute divisions based on religious origins. ${ }^{14}$ There is no doubt that Ottoman society was different from its Western contemporaries, and to some extent even its antecedents in the Middle East from which its institutions and culture derived. ${ }^{15}$

The question that concerns us is, where did the court physicians fit in this "monde renverse'"? Were they part of the Ottoman élite as civil servants? What was their position at the Ottoman court? This paper will attempt to provide some answers by examining their role, function, and training, which have hardly been systematically looked at. Some of the source material in European archives, ranging from diplomatic documents to accounts of travellers and contemporary histories, has been

\footnotetext{
${ }^{10}$ Paul Rycaut, The present state of the Ottoman Empire. Containing the maxims of the Turkish politie ... and a particular description of the Seraglio, London, 1668, ch. iii, 9.

${ }^{11}$ The decline and fall of the Roman Empire, London, 1890, vol. 4, p. 419.

12 A. H. Lybyer, The government of the Ottoman Empire in the time of Suleiman the Magnificent, Harvard Historical Studies 18, Cambridge, Mass., 1913, esp. pp. 36-7. Lybyer seems to have written in the spirit of the earlier European observers, namely to illuminate the "secrets of Ottoman greatness and success": see the preface.

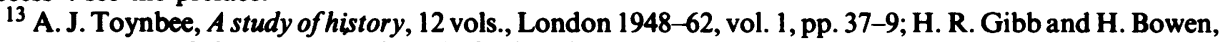
Islamic society and the West, London, Oxford University Press, 1950-7, vol. 2, pt. 1, esp. pp. 43-5.

${ }^{14}$ For a critical evaluation of the Lybyer thesis, see Norman Itzkowitz, 'Eighteenth century Ottoman realities', Studia Islamica, 1962, 14: 73-94. Although it focuses on the eighteenth century, its argument, that career opportunities in the Ottoman system of government were not determined by religious origin, also applies to earlier periods.

${ }^{15}$ For a clear outline of the Ottoman institutions, see idem, 'The Ottoman Empire: the rise and fall of Ottoman domination', in Bernard Lewis (ed.), The world of Islam, London, Thames \& Hudson, 1976 pp. 278-84.
} 


\section{G. A. Russell}

published and utilized, but the vast amount of documents in the Ottoman State Archives (some of which are written in an extremely difficult and coded script to prevent forgery) remains virtually untapped. These include registers for palace expenses and for wages of palace employees as well as decrees and orders to officials, reports received, petitions, grants of land, privilege, and title, and charitable bequests, among others. ${ }^{16} \mathrm{~A}$ thorough investigation of physicians at the court of the Ottoman Empire would require the full use of such sources. This paper will, therefore, be a preliminary attempt, remaining on the whole within the period 1525-1650, a framework provided by the pay registers of the Imperial Treasury for physicians and surgeons which have been used for this study. ${ }^{17}$

Before such an examination, it is essential to briefly outline the structure of the Ottoman court and its key institutions, the Palace School (Enderūn-i Humāyūn) and the devshirme system which underlay it.

\section{THE DEVSHIRME: A SYSTEM OF SELECTION}

The Ottoman system of government was primarily concerned, in addition to the affairs of state, with the administration of its law in an intricate, hierarchical organization centred around the Palace. The executive power of the State devolved from the Sultan through the Grand Vizier and the members of the Imperial Council, which included the highest military, financial, administrative, and judicial representatives of the government. ${ }^{18}$ The decisions of the Imperial Council were implemented by a highly centralized bureaucracy.

The career divisions (the military, the bureaucracy, and the religious authorities or 'ulemā) formed a stratified society of great complexity and surprising stability. At the same time, it was based on principles which were contrary to notions of social stability in the West, where the family was an essential ingredient in the evolution of a class structure as well as a major element in political developments. The Ottoman state attempted and to a large extent succeeded in excluding the family as a significant factor in the distribution of power, privilege and wealth by institutionalizing a denial of the hereditary principle in its law of feudal land-holding, the timar system. In principle, advancement was not dependent on family lineage or hereditary privilege and ownership of land. The Ottoman élite was neither born nor self-made. Its members were selected in childhood and trained by the Palace.

This vital and characteristic feature of the Ottoman court, and by extension the Ottoman state, was the system of the $\mathrm{kul}$ or servant-slaves. ${ }^{19}$ These were procured

${ }^{16}$ S. J. Shaw, 'Archival sources for Ottoman history: the archives of Turkey', J. Am. Orient. Soc., 1969, 80: 1-12. For a more recent guide, see Ottoman archives, prepared by N. Aktaş and I. Binark and edited by E. İhsanoğlu (Istanbul, 1986). On Palace expenses, O. L. Barkan, 'Istanbul Saraylarına ait muhasebe defterleri', Belgeler (Ankara), 1979, 9: 1-380.

${ }^{17}$ Some of these have been published by R. M. Meriç, 'Osmanlı Tababeti Tarihine Ait Vesikalar', Tarih Vesikaları (Ağustos), 1955, 1 (16): 37-113; and ibid. (Ocak), 1958, 2 (17): 267-93. In outlining the nature of training in Ottoman medical profession (1955, pp. 34-6), he unfortunately does not provide sources for his statements.

${ }^{18}$ For a description of the Ottoman system of government, see Inalc1k, 'The state', in op. cit., note 1 above, esp. pp. 65-104.

${ }^{19}$ For a comparison of Ottoman and European approaches to slavery and notions of a "slave", see P. Cole, 'The structure of the Ottoman Empire', in The Ottoman impact on Europe, London, 1968, esp. pp. 46-59; I. Metin Kunt, The Sultan's servants: the transformation of Ottoman provincial government 1550-1650, New York, Columbia University Press, 1983. 

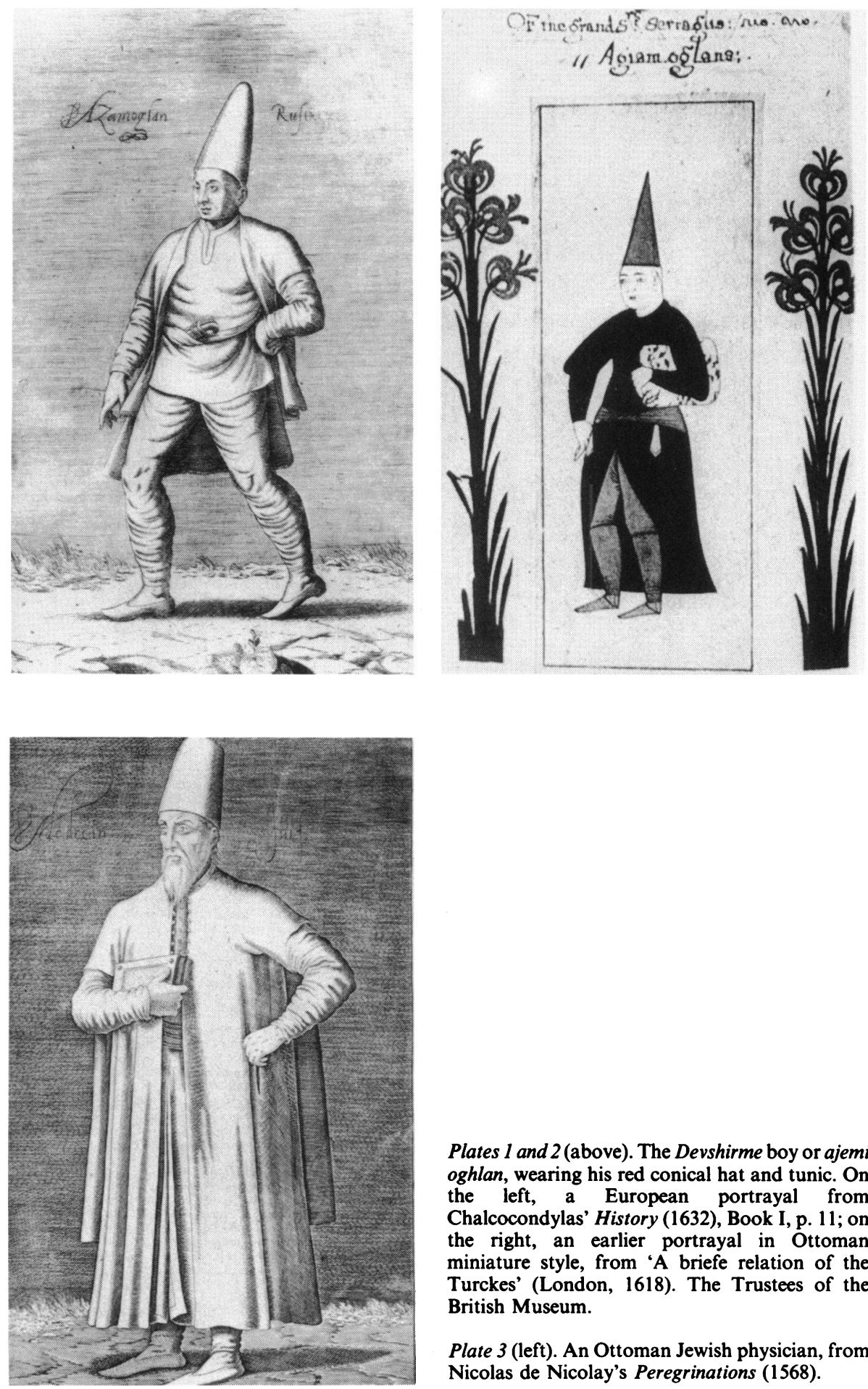

Plates 1 and 2 (above). The Devshirme boy or ajemi oghlan, wearing his red conical hat and tunic. On the left, a European portrayal from Chalcocondylas' History (1632), Book I, p. 11; on the right, an earlier portrayal in Ottoman miniature style, from 'A briefe relation of the Turckes' (London, 1618). The Trustees of the British Museum.

Plate 3 (left). An Ottoman Jewish physician, from Nicolas de Nicolay's Peregrinations (1568). 


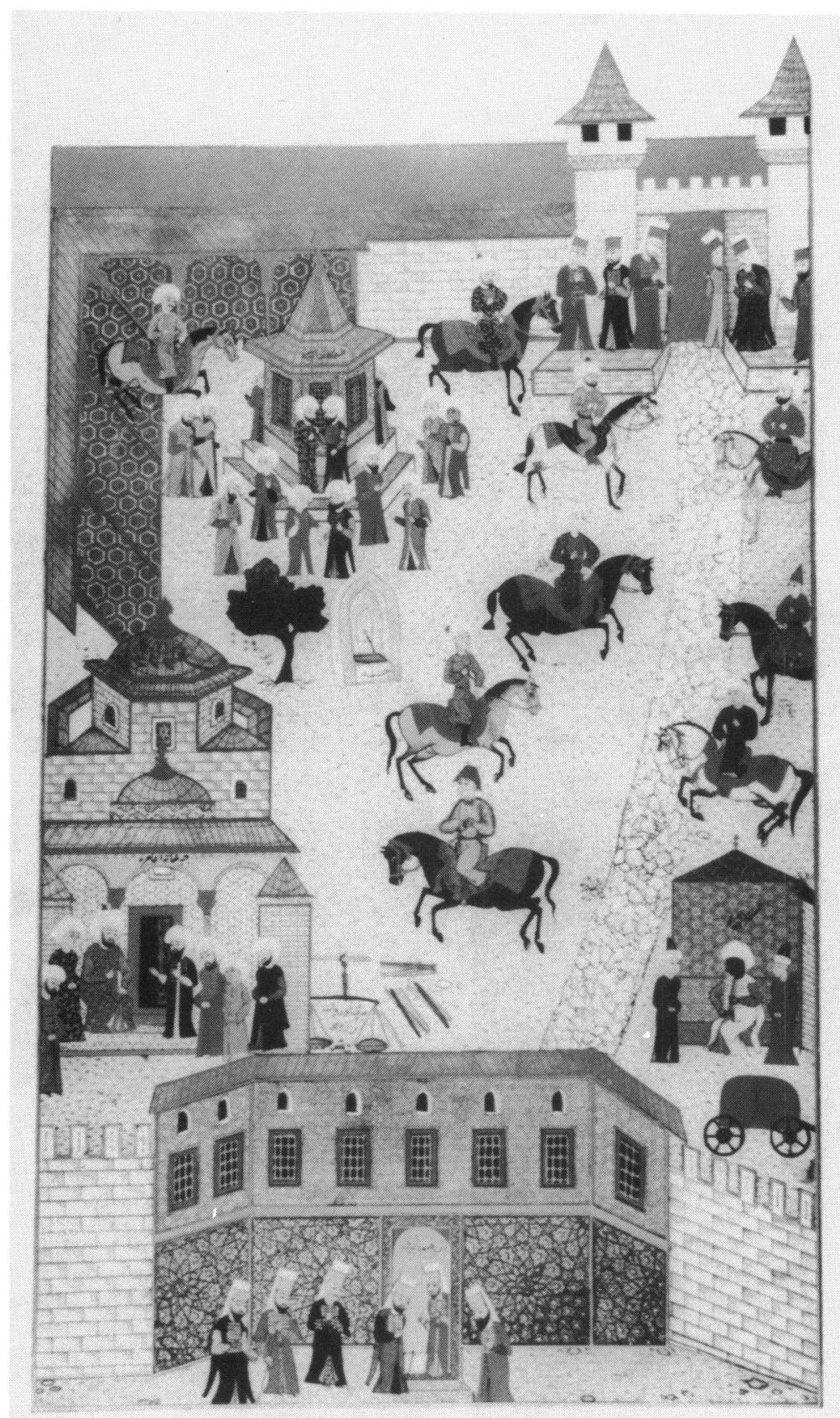

Plate 4. The First Courtyard of the Palace. At the bottom right, behind the outer gate, is the infirmary with a black eunuch and two orderlies on duty. The covered litter, which is described in a number of foreign accounts, can be clearly seen in this early Ottoman miniature by Molla Tiflisi in the Hünernāme, which was composed between 1578/9 and 1584/5. Topkapı Saray Hazine Kütüp, no. 1523, vol. 1, fol. 15b. 


\section{Physicians at the Ottoman Court}

from among prisoners of war, in slave markets, and from what was known as the devshirme: the recruitment of boys specifically, though not entirely, from the Christian population of eastern Europe. For example, the Bosnians who had already been converted, were taken at their own request. The devshirme was regarded as an extraordinary levy in response to the urgent need for military and administrative manpower in a rapidly expanding empire, and came to include the Sultan's Asiatic domains. $^{20}$

When the need arose for the devshirme in an area, a commissioner was appointed by the Sultan's Fermān, or edict. ${ }^{21}$ Furnished with a warrant of authorization together with a supply of uniforms (a red tunic and a conical hat), and accompanied by a Janissary official, he went to the designated districts. Summoned by criers, the boys were assembled with their fathers and priests who brought their baptismal records to be checked by the local kādis (judges) and the sipāhis (feudal lords). Under their supervision, the commissioning officer selected the best of the youths of eligible ages, which ranged from 8 to 18 or 20 . The qualifications for recruitment were itemized in great detail: a son would be taken only from a familly of two or more; orphans, those who were their parent's sole support, and those who were married or engaged in any trade were not eligible. ${ }^{22}$ They had to be physically fit and socially unsophisticated, with no town experience. Their names, parentage, age, place of birth, and physical descriptions were listed in two separate registers. One copy remained with the recruiting officer, the other went with the drover (sürüjü) who conducted the youths in groups of one or two hundred to the Janissary headquarters. There the two copies of the register were compared to prevent the boys being bought out of the devshirme, substituted, or included illegally along the way (plates 1 and 2). ${ }^{23}$

On arriving at the capital, they were formally admitted to Islam by raising their right hands and reciting the profession of faith. After being examined by a special surgeon (jerräh) assigned to the task, they were circumcised. The best, usually about ten per cent, were selected for the Palace as pages (ich oghlan) to be trained at the Palace schools. The rest were hired out either to feudal cavalry (sipāhis) or to work on the land in Anatolia in order to toughen their bodies, learn Turkish, and to assimilate the customs and religion. When needed, they were called in and, after careful consultation of their records, assigned to various services at the Palace or directly to the formidable infantry corps of the Janissaries (Yenicheri). ${ }^{24}$

\footnotetext{
20 The devshirme reinforced the supplies from the "slave" farms specially cultivated by the Georgians and the Crimean Tartars in the Black Sea. As Inalcik has pointed out (op. cit., note 1 above, pp. 77-8), government did not consider the devshirme as an enslavement of its own subjects but simply as an extraordinary levy (every three to seven years as the need arose) with numerous exemptions. See also s. v. "Ghulām" in the Encyclopaedia of Islam, 2nd ed., Leiden, 1965.

${ }^{21}$ The levies of Christian children have received a great deal of attention in European accounts. For a detailed description of the devshirme system, based on archival sources, see I. H. Uzunçarşıll, 'Acemi Ocaği Teşkilatı: Devshirmeler', in Osmanlı Devleti Teşkilatından Kapıkulu Ocakları, vol. 1, Ankara, 1943, pp. 13-30; Inalck, op. cit., note 1 above, pp. 77-8; and especially V. L. Ménage, s.v. "Devshirme" in the Encyclopaedia of Islam, 2nd ed., Leiden, 1965, on which the following account is based.

22 For exemptions and qualifications, see Uzunçarşıl, op. cit., note 21 above, pp. 16-21.

${ }^{23}$ For a sample of an entry from such registers (Mühimme Defteri 24, fol. 28), see ibid., note 1, p. 23.

24 Ibid., pp. 23-4; Inalc1k, op. cit., note 1 above, pp. 78-9; V. L. Ménage, 'Some notes on the devshirme', Bull. Sch. Orient. Afr. Stud., 1966, 29: 64-78.
} 


\section{G. A. Russell}

Those who were selected for the Palace schools embarked on a rigorous military and vocational training. ${ }^{25}$ Initially cut off from their earlier lives and any contact with women, the youths became completely dependent on the Sultan. Rising through a hierarchy of positions, they could eventually occupy powerful administrative and Palace posts, even the highest of all, that of the Grand Vizier. As kapikulu, literally in the service of the Porte, they owed (though they did not always give) unquestioning obedience and loyalty to the Sultan. At the same time, they belonged to a privileged élite, an élite that could not, however, transmit its rights to its descendants.

The devshirme system in combination with the Palace schools, as one of the main routes to high office, provides a concrete illustration of social mobility in the structure of the Ottoman society. The full extent to which it moulded the mentality of its members and the nature of its institutions has not, however, been sufficiently investigated. This social mobility also opened the path to a glittering career for ambitious foreigners, frustrated in their own countries, to seek their fortunes in the Ottoman Empire and to "turn Turk".

TRAINING AT THE PALACE SCHOOL

There were no limits, it seems, to the authority or wealth to which the pages could aspire except those set by their own ability, ambition, and loyalty. At least this was the impression in European accounts. Blaise de Vigenere, in his translation and continuation of Chalcocondyles' History, stated in 1577: "It should be understood, first of all, that the whole establishment of the sultan's court, the foundation of his empire, and the strength of his army depend upon a permanent seminary of youth".26 Although such a portrayal may be inaccurate and somewhat exaggerated, there is no question that sons of ignorant peasants became men of education, culture, and extraordinary ability. In fact, they defined what came to be understood by the concept of "Ottoman".

Underlying this transformation was the Palace School where, in addition to the devshirme youth, slaves purchased or received as gifts, prisoners of war, renegades, hostage princes (Christian or Muslim), and sons of high-ranking officers were educated together. Turkish boys who showed promise could also be taken in from outside the Palace, with the Sultan's permission. ${ }^{27}$ Evliyā Chelebi, the indefatigable traveller and weaver of fact and fiction, was one of them. ${ }^{28}$

\footnotetext{
${ }^{25}$ Miller, 'Palace School', op. cit., note 2 above, pp. 47-71; for a more detailed treatment, see idem, The Palace School of Muhammed the Conqueror, Harvard Historical Monographs 17, Cambridge, Mass., 1941.

${ }^{26}$ Laonicus Chalcocondyles, De origine et rebus gestis Turcorum libri decem, nuper è Graeco in Latinum conversi: Conrado Clausero ... interprete, Basel, 1556. Transl. by Blaise de Vigènere (or Vigènaire) as Histoire de la décadence de l'Empire grec, et établissment de celuy des Turcs, Rouen, 1660, English translation in Miller, Palace School, op. cit., note 25 above, p. 6.

${ }^{27} \mathrm{R}$. Withers, A description of the Grand Signor's Seraglio or Turkish Emperior's Court, London, 1650, p. 68. European accounts tend to borrow from each other without acknowledgement and must not be regarded as independent observations always. Wither's, for example, comes from the Venetian bailo Ottoviano Bon's account, written between 1604 and 1607.

${ }^{28}$ Miller, Palace School, op. cit., note 25 above, pp. 83-5; Evliyā Chelebi, Seyāhatnāme [Travels], ed. N. Asım, Kilisli Rifat, and N. H. Orkun, 10 vols., Istanbul, 1896-1938. An incomplete English translation is the Narrative of travels in Europe, Asia and Africa in the seventeenth century, 2 vols., London, 1834.
} 


\section{Physicians at the Ottoman Court}

Starting with preparatory schols, including three auxiliary ones at the Edirne, Galata, and Ibrahim Pasha Palaces, the training extended over a period of 14 years in a carefully graded hierarchical structure. Supervision and discipline was in the hands of the white eunuchs (ak aghas), themselves products of the same education. They were organized in an elaborate hierarchy, in which the highest rank was that of the head of the whole school. ${ }^{29}$ After the initial phase lasting from two to seven or eight years, the pages underwent selection. The best went on to continue training in the two preparatory halls of the Palace, the Great Hall and the Small Hall. In the sixteenth century the number of pages in the two halls is put as high as 700. After an additional four years of training, the most able and promising were taken into the four vocational halls: the Campaign Hall, the Commissariat, the Treasury, and finally the most prestigious, the Privy Chamber directly concerned with the Sultan's activities. ${ }^{30}$ The process by which the pages were reviewed, promoted, and selected was referred to as the chikma, literally "coming out", whereby they finally took up positions within the Palace or sent outside (tashra) to military, civil, or provincial administrative posts. Senior pages left the Palace between the ages of 25 and $30 .^{31}$

The school buildings, which formed the quadrangle of the third court and served as a sort of antechamber to the private apartments of the Sultan, consisted of classrooms, dormitories, a bath, an infirmary, a library, a conservatory of music as well as the stables and games fields. ${ }^{32}$ Descriptions of the School have stressed the curriculum as its significant feature. ${ }^{33}$ Although more research is needed about the nature of subjects taught before anything can be stated with certainty, it seems to have gone beyond the medrese system by combining religious, secular, military, physical, and vocational training within a centralized institution. ${ }^{34}$ It was reported in contemporary accounts that the "dispositions and the inclinations of the pages" were "carefully consulted". The course of study has been described as being almost entirely a matter of individual choice. ${ }^{35}$ No explanation has, however, been provided either in these accounts or in the more recent studies of the Palace School as to how that choice was made available. For vocational training there is, however, evidence of the incorporation into the school of an apprenticeship system closely resembling that of the guilds, thereby giving it considerable flexibility. By arrangement with individual masters, it would have enabled training in a wide range of crafts or professions and taken into account the inclination and aptitude of the pages, each of whom had to acquire a specific skill, or specialize in a particular service. ${ }^{36}$ This is borne out by the

\footnotetext{
${ }^{29}$ Miller, op. cit., note 2 above, pp. 60-1 and idem, Palace School, op. cit., note 25 above, pp. 86-90; Inalck, op. cit., note 1 above, pp. $79-80$.

30 The Campaign Hall was added in the seventeenth century: ibid., p. 80.

31 Ibid., pp. 79-81; Miller, op. cit., note 2 above, pp. 55-7.

32 Ibid., p. 59. Rycaut, in his description of the "Education of young men in the Seraglio", mentioned a separate school for music: op. cit., note 10 above, ch. v, 32.

33 Miller, Palace School, op. cit., note 25 above, pp. 4-5.

34 For a description of the education at the Palace School and its curricula, see idem, 'The curriculum of the Palace School of the Turkish Sultans' in The Macdonald presentation volume, Princeton University Press, 1937; and Palace School, op. cit., note 25 above. A contemporary account is in Rycaut, "Of the method of the Turkish Studies and Learning in the Seraglio", op. cit., note 10 above, ch. vi, 30-3.

${ }^{35}$ Miller, op. cit., note 2 above, p. 64.

${ }^{36}$ Withers, op. cit., note 27 above, pp. 78-80.
} 


\section{G. A. Russell}

fact that in addition to the instructors of the School, others were drawn from institutions outside the Palace, such as the medreses, as well as from among the distinguished scholars who were resident in or associated with the Palace. ${ }^{37}$

Underlying the School, as well as the Palace as a whole, was a system of merit with carefully graded rewards and corresponding punishments. Incentives to accomplishment were in the form of wages on a differential scale, as in government service, and appointments to a hierarchy of student offices. Not only promotions from one hall to another, but also final elevation to military or administrative posts were all based on seniority and preferment. ${ }^{38}$

It is important to bear in mind that it was the nature of Ottoman power to centre above all on the person of the Sultan, in a loyalty independent of regional, ethnic, and even religious considerations. Therefore, both the highest and lowest common denominator of this system of advancement was service to the throne. Cut off from family and outside patronage, promotion was entirely dependent on subservience and loyalty. To Europeans, however, such a system appeared to offer limitless preferment to talent without the constraints of genealogy. As Gibbon eloquently summarized it,

In the slow and painful steps of education, their characters and talents were unfolded to a discerning eye: the man, naked and alone, was reduced to the standard of his personal merit; and if the sovereign had wisdom to choose, he possessed a pure and boundless liberty of choice. ${ }^{39}$

Sixteenth- and seventeenth-century observers of the Ottoman Empire became aware of the importance of the Palace School and the devshirme system through the occasional first-hand information provided by former pages, such as Menavino, a Genoese captive, whose Trattato de' costumi et vita de Turchi was published in Florence in 1548, and particularly Albert Bobovius, a Pole known as 'Ā $\bar{l}$ ī Bey, who served at the Palace for 19 years during the reigns of Murād IV (1623-40) and Ibrahim I (1640-48)..$^{40}$ Bobovius was a music page whose predilection for alcohol caused him to be ignominously thrown out of the Palace. Perhaps to get even and to support his habit, he seems to have peddled his disclosures of the secrets of the Seraglio to various embassies. The success of his attempt is seen in the repeated editions of his Serrai enderum [sic] in Italian, French, and German between 1665 and 1679.41

Paul Rycaut, in The present state of the Ottoman Empire (1668), largely taken from Bobovius, appraised the training: "if well considered and weighed, one of the most Politic Constitutions in the World, and none of the meanest supports of the Ottoman Empire". ${ }^{42}$ Rycaut seems to have clearly recognized the essential principle of

${ }^{37}$ Miller, Palace School, op. cit., note 25 above, p. 91; Withers, op. cit., note 27 above, ch. 6.

38 G. M. Angiolello, Historia turchesca, Paris, Bibl. Nat., fonds ital. 1238, fols. 50-51; in Miller, op. cit., note 2 above, p. 54.

${ }^{39}$ Gibbon, op. cit., note 11 above, vol. 4 , p. 420.

40 Prior to the seventeenth century, in addition to that of Giovanni Antonio Menavino, the accounts of Angiolello (op. cit., note 38) and Luigi Bassano da Zara, I costumi et i modi particulari de la vita de' Turchi, Rome, 1545, are by former pages.

${ }^{41}$ For a bibliography on Bobovius, see Miller, op. cit., note 2 above, p. 264.

42 In 'The epistle to the reader', Rycaut stated that "The relation of the Seraglio, and Education of their Youth, with divers other matters of Custom and Rule were transmitted to me by several sober Persons, 


\section{Physicians at the Ottoman Court}

obedience underlying the system: that to govern justly, one has to first learn how to obey. ${ }^{43}$

Earlier in the century, Michel Baudier, later the royal historiographer of France, also commented on the value of the Saray education in his Histoire generalle du serrail et de la cour du Grand Seigneur, empereur des Turcs:

It is not surprising that the Turkish nation prospers, since the Turks know how to choose the élite from the great numbers of youths and how to give them the instruction and discipline which makes them honest men, thus adjusting to the gifts of nature, the perfections of art. The order and the method with which these youths are trained, show certainly that the Turks have retained nothing of the barbarism except the name. ${ }^{44}$

Baudier's comment touches on the crucial and curiously neglected question, of how the Ottomans chose the élite from the great number of youths. Indeed, what was the "order and method", which, in the words of Gibbon, "extorted the reluctant praise of their Christian enemies"? ${ }^{45}$

The answer comes not from modern historians but from an Ottoman historiographer almost contemporary with Baudier. In his Künh al-ahbār of 1597/8, Mustafa 'Âli $(1541-c .1600)$ clearly stated that on the board of initial selection was an expert in 'ilm-i kiyaffe, in other words, the science of physiognomy. ${ }^{46}$ This statement is corroborated by the importance given to physiognomy in the manuscripts which were prepared specifically for the Sultans, who at times presided personally over the selection. ${ }^{47}$ A preliminary survey of extant physiognomy texts from Instanbul libraries contains nine Ottoman manuscripts copied between 1530 and 1585 , more than half of which were prepared for the reigning Sultan. ${ }^{48}$

Not only were the youths for the devshirme and the Palace School selected on the basis of physiognomy, but the promotions to high offices may have been determined with reference to physiognomic principles. For example, the introduction to a sixteenth-century text by Muștafā b. Evrenos throws light on the application of physiognomy. The author attempted to prepare, from Arabic and Persian sources, a treatise on physiognomy ('ilm-i kiyäfe ve firāse) so that the Sultan might,

acquire the skill and expertise to discern their inner character from outward behaviour, and from their external appearance the true nature of his $\mathbf{k u l}$ [servant slaves], ulüfeci [Janissaries], and those in the hierarchy of government, and even his subjects

trained up with the best Education of the Turkish learning; particularly, by an understanding Polonian who spent nineteen years in the Ottoman Court." The latter is clearly Bobovius.

43 Rycaut, op. cit., note 10 above, 42.

${ }^{44}$ Paris, 1624; in English, The history of the Serrail and of the Court of the Grand Seigneur, Emperour of the Turkes, transl. Edward Grimstone, London, 1635.

45 Gibbon, op. cit., note 11 above, vol. 4, p. 420.

46 Istanbul, Nuruosmaniye Kütüp., 3407, fol. 14; Mevā'id al-Nefá'is fi Kavā'id al-Mejälis, Istanbul, 1956, fols. 20-22, 247; for biographical information, see Cornell H. Fleischer, Bureaucrat and intellectual in the Ottoman Empire. The historain Mustafa 'Ali (1541-1600), Princeton University Press, 1986.

47 Rycaut, op. cit., note 10 above, ch. v, 26.

48 Hayyampur, 'Kiyafetnameler', diss., Istanbul University, 1941, pp. 17-43; an. uncritical survey. I am indebted to V. L. Ménage who generously let me have his list of the kiyâfa manuscripts in Instanbul libraries and drew my attention to this reference, and to Feza Günergün and Ekmeleddin Ihsanoğlu, who procured it from the University Library of Istanbul. 


\section{G. A. Russell}

$\left[r e^{\prime} \bar{a} y a\right], \ldots$ thereby to appoint each according to his worth, whether he is fit for the [offices of] vezäret, sanjak, aghälik, or for trust .... ${ }^{49}$

Rycaut, in the Maxims, pointed out that the "youths must be of admirable features, and pleasing looks, well-shaped in their bodies and without any defects of nature. For it is conceived that a corrupt and sordid soul can scarce inhabit in a serene and ingenious aspect."

Physiognomy had been inherited from the classical and Hellenistic world. ${ }^{50}$ As a practical science based on humoral physiology, with extensive support from medicine, it was used in the Islamic world particularly in buying slaves. ${ }^{51}$ What the Ottomans seem to have done was to elaborate the classical and Arabic paradigms and to create from them a court profession. Whether they added anything to the theoretical and psychological basis of physiognomy, which was already highly developed, is doubtful. They seem, however, to have institutionalized a physiognomist, or kiyāfetshinās, at the court, who clearly had a vital role. ${ }^{52}$ Where family was excluded from its usual place in society, physiognomy was its surrogate, constituting the essential vehicle for the replenishment of kapikulu for the Porte.

It should be mentioned that, while sevententh-century Western observers of the Ottoman world still expressed their admiration for the Ottoman system of preferment based on merit, perceptive Ottoman statesmen, such as Kochu Bey, had a less romantic view. In his Memorandum or Risāle of 1630, to be presented to the autocratic Sultan Murād IV, Kochu Bey, a product of the devshirme and the Palace system, attributed the decline of the Empire to the corruption of its institutions, to the fact that moral deterioration and favouritism had replaced integrity, dedication, competence, and merit: "men with neither aptitude nor experience of affairs came and sat in the seats of power". 53

\section{PHYSICIANS AND SURGEONS}

The Palace school system not only prepared administrators for the Empire, but provided vocational training in a wide range of crafts and professions. Curiously, neither in connection with the devshirme system, nor in the contemporary or modern descriptions of the Palace School is medicine discussed. ${ }^{54}$ Yet not only physicians but also surgeons and oculists were employed in substantial numbers by the Court. Where

\footnotetext{
${ }^{49}$ Klyäfet, Atif Ms. 2162, author's translation. This manuscript is not included in Hayyampur's dissertation. Evrenos' introduction seems to be highly representative. A kıyäfetnāme copied in 1518 (London, Wellcome Institute, Ms. Turkish, Med. 6, fol. 7r) was, for example, prepared to demonstrate that the science of phsyiognomy should not be restricted to the use of Sultans and those in high places alone. See, G. A. Russell, A catalogue of Turkish manuscripts in the Wellcome Library, (forthcoming).

${ }_{50}$ Youssef Mourad, La physiognomonie arabe et le 'Kitāb al Fìnāsa' de Fakhr al-Dīn al-Rāzī, Paris, 1939.

${ }^{51}$ Hans Müller, Die Kunst des Sklavenkaufs: nach arabischen, persichen und türkischen Ratgebern vom 10. bis zum 18. Jahrhundert, Freiburg, Schwarz, 1980; Kai-Kā'ūs b. Iskandar, A mirrer for princes: the Qābüs-nāma, transl. Reuben Levy, London, Cresset Press, 1951.

52 Uzunçarsıl, op. cit., note 21 above, p. 23.

53 Quoted from a manuscript in ibid., p. 201; on the Memorandum of Kochu Bey see Ali K. Aksut (Istanbul, 1939); also Bernard Lewis, for Kochu Bey and other 'Ottoman observers of Ottoman decline' in Islam in history, London, Alcove Press, 1973, pp. 199-213; esp. note 16, p. 326.

${ }_{54}$ Medicine is hardly mentioned in Osman Ergin, 'Enderun Mektebi', Istanbul Mektebleri ve Ilim Terbiye ve San'at Müesseseleri Dolayısıyla Türkiye Maarif Tarihi, Istanbul, 1939, pp. 6-16.
} 


\section{Physicians at the Ottoman Court}

did they come from? Were they products of the devshirme and the Palace School? Or did they constitute the exception to the kapikulu? The key to these questions lies in the Defter, the pay registers of the Ottoman Imperial Treasury. For example, the court physicians (ețibba'-i hassa) appear in the registers for Palace officials, Defter-i mevājib-i jemā 'āt-i mushāhere-borān. ${ }^{55}$ The surgeons and oculists are included in the registers for Palace craftsmen, artisans, and guild members, Defter-i mevājib-i jemā'ät-i ehl-i hıref. ${ }^{56}$ Although the number of physicians, surgeons, and oculists who were on regular pay at different times and in the reign of different Sultans can be deduced from them, these documents are not simply quantitative lists. Taken together with the use of physiognomy and the Palace School system, they throw light on the way the physicians and surgeons were selected, trained, and evaluated for promotion. For example, in the registers for surgeons and oculists for the years 1525 to 1650 , the brevity of the entries disguises a wealth of detail. ${ }^{57}$ Each entry follows a specific pattern. First the name of the individual is given, usually accompanied by a second name which tends to indicate where he originally came from. This is followed by salary. In a hierarchical system where promotion was geared to evaluation, salary indicated position or seniority. Therefore, any salary increment received, for example, at the accession of a Sultan, was noted. Then comes where, when, and in what capacity the individual joined the Palace medical staff. Although this information could be in the form of one or two words, it can reveal whether he came as devshirme (from the Balkans or Anatolia); or whether he was transferred from the medical corps of the Janissaries, the Palace School (the external ones at Edirne and Galatasaray, or in the Palace itself), or the Palace service (Hässa). This is followed by the name of the Sultan under whose reign he joined, usually indicated as "came with". We can also learn whether he came from a medical family (indicated by the "son of") as sons tended to follow in the professions of their fathers, or apprenticed to a well-known master. ${ }^{58}$ Since the names of the masters are mentioned, we can learn not only with whom the surgeons and oculists were trained but also how they acquired their previous training. As a final item, we seem, interestingly, to have an evaluation of aptitude, where it literally says, for example, "ability one" (käbiliyyet bir: out of 50 entries, for instance, only three are designated as such). ${ }^{59}$

\footnotetext{
55 This group of Palace officials included entertainers, buffoons, dwarfs, poets, musicians, pastry cooks, and spies.

${ }^{56}$ For the extensive range of craftsmen and artisans employed by the palace on regular wages, see I. H. Uzunçarşılı, 'Osmanlı Saray'inda Ehl-i Hiref (Sanatkarlar) Defterleri', Belgeler (Ankara), 1986, 11: 23-76.

57 The following analysis is based on the registers published in R. Melul Meriç, 'Cema'āt-i Cerrāhīn ve Kehhālīn', Tarih Vesikaları, 1955, 1(16), pp. 37-113 and ibid., 1958, 2(17), pp. 267-93. Starting with the earliest register of AH 932/1525 AD (D.9613), the documents under consideration continue, at three-monthly intervals, when salaries were paid, until 1063/1652. The pay was in akcha, calculated on a daily basis.

58 By the seventeenth century, it was customary for sons to follow in the careers of their fathers in the 'ulemā and the Janissaries. See Kātip Chelebi, Mizān al-Hakk, transl. by G. L. Lewis as The balance of truth, London, 1957, p. 135. The Treasury registers show this to be true for the medical profession as well. On court apothecaries at the Palace in the sixteenth and seventeenth centuries, see Arslan Terzioğlu, 'Eine bisher unbekannte Handschrift über die Herstellung der Arzneien im Topkapi-Palast in Istanbul', Z. Gesch. arab.-islamischer Wiss., 1987-8, 4: 160-74.

59 The documents for 1525-26 (Belge, Nos. 22 and 23) reproduced in Uzunçarşılı, op. cit., note 56 above, pp. 61-4, overlap with those published by Meriç (Topkapı Sarayı Ar. D: 9613-2), op. cit., note 57 above, pp. 37-40. Out of 50 surgeons, 19 had the rating of "one" for skill (san'at bir) as opposed to the three surgeons awarded it for ability or aptitude (käbiliyyet bir).
} 


\section{G. A. Russell}

What emerges from an examination of these documents in chronological order is first, a clear indication that the devshirme and the Palace School system provided not only the military and the administrative élite but also the court physicians and surgeons. In the early registers, for instance, the majority of the staff undoubtedly comes from the devshirme in the Balkans, followed to a lesser extent by names indicating Polish, Hungarian, and Austrian origin, most probably as penjik or prisoners of war; and finally by those of Anatolian (eastern provinces), Georgian, or Circassian origin. Classified together with craftsmen, artisans, and members of professional guilds, their training at the Palace School would have started at the stage where, after the initial general education, the pages who showed aptitude were placed as novices under a master to learn various trades and skills. ${ }^{60}$ Their medical education would have consisted of both theoretical and practical training, with promotion from one grade to another depending on the recommendation of their masters. ${ }^{61}$ The range of available medical texts could be gleaned from an extant list of books in the keeping of the Chief Physician, for the purpose of instruction during his term of office. $^{62}$

In addition to the pages, for example, from among the élite corps of the sons of high officials and vassal lords, which formed a separate group in the outer palace, those who had already applied for training were also taken according to need. ${ }^{63}$ Both the numbers of trainees and the type of training seem to have been determined by the requirements of the jobs, whether in the inner or the outer palace, for war or for peace. Upon completion of training, the candidates put their names on the register-books for the posts for which they wished to apply and waited for a vacancy to occur. ${ }^{64}$ As kapikulu, they could also be assigned to the Janissary medical corps, which consisted of a physician, a surgeon, and a number of assistants ( $\mathrm{kalfa}$ ), as well as a mobile unit to transport the sick. ${ }^{65}$

If a physician, surgeon, or oculist was kept waiting without wages, then upon his appointment to a vacant position, he would receive compensation for the period during which he was deprived. If for any reason he did not get his due, he could submit a letter of application to the Grand Vizier or even the Sultan himself. In addition to vacancies due to deaths and other causes, those who held high positions had an allotment for a certain number of appointments or müläzemet. For example, the Chief Physician was entitled to fill four appointments at specific times, such as the

\footnotetext{
60 This is clearly shown in the registers, where the name of a "master" (usta or ustād) such as the Chief Surgeon, Master Sinan, frequently recurs with references to his "able" pupils or simply to his apprentices. From AH 1004/1595 AD the separate listing of apprentices becomes more consistent.

${ }^{61}$ According to Meriç, op. cit., note 57 above, p. 36, what the apprentices learned from their masters was taken down in notebooks to be consulted when required. No such notebooks, however, have as yet come to light.

62 Topkapı Sarayı Ar.D. 8228, reproduced in N. Sarı, 'Educating the Ottoman physician', Tip Tarihi Arasttrmalart, 1988, vol. 2, p. 52, who also states (p. 46) that according to a note on the back of the document, the books were given in 1575 to one Chief Physician who transferred them to his successor in 1580 .

${ }^{63}$ From $1013 / 1604$ the registers also have a separate list for the müteferrika corps, which remains fairly small in number.

${ }_{64}$ Meriç, op. cit., note 57 above, pp. 34-5.

${ }^{65}$ Uzunçarşıll, op. cit., note 21 above, p. 405 ; Meriç, op. cit., note 57 above, p. 35.
} 


\section{Physicians at the Ottoman Court}

accession of a new Sultan. ${ }^{66}$ Those who worked well and showed promise would be rewarded by a pay rise. These increments would be transferred from the wages of apprentices and masters who had died. Those who did not do well in a particular post (jema' 'àt or ojak) would be removed or transferred elsewhere. These appointments were made upon the recommendation of the Chief Physician together with that of the chief Clerk. ${ }^{67}$ The registers kept a close account of each individual's pay, former post, and new appointment, as well as his training and accomplishment.

In addition, physicians were also taken from outside the court, where a special medical medrese provided medical education. This is a development for which there was no precedent in previous Islamic societies. In the Ottoman Empire, medreses from the time of Sultan Mehemmed II seem to have become centralized educational institutions with a specified curriculum. They had teaching halls, and provided accommodation, meals, and study facilities for the pupils. ${ }^{68}$ The medical medrese established by Suleyman II in 1551 became a prestigious higher institution. The appointment to the head of the Süleymaniye medical medrese was usually preliminary to that as Chief Physician at the Palace. ${ }^{69}$

Another institution for training physicians, and particularly surgeons, was the hospital. ${ }^{70}$ As early as the fifteenth century, hospitals attracted students even from outside the provinces of the Empire. For example, Sharaf ad-Dīn ibn 'Alī ibn al-Hajj Ilyās Sabunjuoghlu (fl. c. 1404-69), the author of the extensively illustrated surgical manual Jerrāhiye-i Ilbāniya, trained pupils from Persia in the Amasya Hospital (Dār al-Shifä). ${ }^{71}$ It was not unusual for Chief Physicians to be appointed from hospitals outside Istanbul. For example, Emir Chelebi (d. 1638), Chief Physician in the reign of Sultan Murād IV, had previously been the head of the great Kälāwun hospital in Cairo. Highly recommended, ambitious physicians from the provinces could also rise to this coveted post. ${ }^{72}$

${ }^{66}$ I. H. Uzunçarşılı, 'Müderrislik için Mülazemet ve Nevbet', Osmanlı Devletinin İlmiye Teşkilatı, Anakara, 1965, p. 47; see also pp. 43-53 for an analysis of the contribution of mülāzemet to the corruption of the Ottoman system of preferment without the previously-required qualification.

${ }^{67}$ Meriç, op. cit., note 57 above, pp. 34-5.

${ }^{68}$ For the organization of medrese education and specifically the Süleymaniye medical medrese, see Uzunçarşıll, op. cit., note 66 above, pp. 1-38, esp. pp. 33-5. He does not, however, discuss any medical curricula; see also idem., note 21 above, p. 365.

${ }^{69}$ Uzunçarş1l, op. cit., note 66 above, pp. 34-5; idem, op. cit., note 1 above, p. 364, n.4. Yet the original charter pays greater attention to the hospital than the medical medrese within the Süleymaniye complex: see K. I. Gürkan, 'Süleymaniye Darüşşifasi', in Känuni Armağanı (Ankara), 1970, no. 7, esp. pp. 262-7. For the hospital, it stipulates three physicians, two surgeons, two oculists, an apothecary with one assistant, and an assistant each for medical preparations, stores, and accounts (treasurer); seven additional positions including a receptionist, cook, and barber; and twelve rooms for the students. The medical medrese, on the other hand, consisted of the Head Physician, as instructor, and eight students. The document also clarifies the nature of their duties and determines the income for both institutions from the islands of Rhodes, Lemnos, and, appropriately, Cos.

${ }^{70}$ Although hospitals provided practical training, charters for the Fātih Hospital show that medical works in Arabic, Persian, and Turkish were available, bequeathed from the Sultan's own collection. See Süret- $i$ Vakfiye-i Ebu'l-Feth Sulțān Mehmed Hän, Topkapi archives, no. 3882, Fatih Mehmed II Vakfiyeleri, Vakıflar Umum Mǜd. Yayın., Türk Vakfiyeleri, no. 1, Ankara, 1938; 46 in Bedi Sehsüvaroğlu, Türk Istanbulda Tıp Öğretiminin 500. Yildönümü, Istanbul, 1971, pp. 37-8.

${ }^{71}$ Ghiyas Ibn Muhammad al-Isphahani, Mir'āt al-Sihhat or Mirror of health (1490), in C. Elgood, 'Safavid surgery', Analecta Medico-Historica (London), 1966, vol. 2; also, 'Introduction', p. xiii.

${ }^{72}$ A. Adıvar, Osmanlı Türklerinde Ilim, Istanbul, 1970, p. 112; Emir Chelebi, Enmūzej al-Ţıb, London, British Library, Ms. Or. 7282, fols, 2-3. 


\section{G. A. Russell}

A document for 1604/5 reflects this variety of training and background represented by the members of the court medical profession. Out of a total of 23 , there were then two oculists, two surgeons, and one physician-astrologer; nine came from medical families (as sons and brothers of head physicians, surgeons, or oculists) with a medrese background; three came from hospitals in Istanbul (Fātiḥ, Bayāzid, and Vālide Sultan); and one was a "Frankish" (i.e., European Christian) convert with prior medical expertise. The backgrounds of the rest are unspecified. ${ }^{73}$

From the Treasury Registers, one learns not only the numbers of physicians, surgeons, and oculists employed at Court, and thereby the ratio of these three professions, but also the ratio of the Muslim to non-Muslim medical staff. Immediately after those of physicians and surgeons, additional lists are given of their apprentices, of the élite corps (Jemà'àt-i müteferrika), and occasionally of converts under the title of "new Muslims". In sixteenth-century documents the number of listed Muslim physicians remains between 13 and 17, whereas the number of Jewish physicians increases considerably, from 5 to 14 . At the beginning of the seventeenth century, there were between 21 and 23 Muslim, and 41 Jewish court physicians. ${ }^{74}$ The document for 1604/5, which names 23 court physicians, separately lists 63 Jewish physicians, Jemā' 'à $t-i$ Etibbā'-i Yahüdiyān, who were attached to the Court. ${ }^{75}$ From the middle of the seventeenth century, however, the numbers seem to have fallen, to 14 Muslims and 4 Jews. ${ }^{76}$ Similarly, in the pay registers for surgeons during the period from 1545 to 1552 , the average number remains between 40 and 50 . At the end of the sixteenth century, however, in the years 1595-99, there was a sudden increase, with the number swelling to 98 , and even as high as $113 .^{77}$

These documents corroborate the observations of such foreign visitors as Nicholas de Nicolay, made in his Navigations of 1551:

In Turkie and principally at Constantinople are found dyuers Phisitions professing the Arte of physicke, and exercysing the practyse thereof, but a greater number of Iewes then Turkes, amongest the which there are many that are skilfull in Theorica, and experimented in practise, and the reason wherefore in this Arte they do commonly exceede all other nations, is the knowledge which they hauve in the language and letters, Greeke, Arabian, Chaldee, and Hebrewe. In which languages as to them partly peculiar, and originall, hauve written the principall Authours of physicke and naturall phylosophie and Astronomie, being the sciences meete and necessarye for those that study physick. Besides the common Phisitions which the Turkes call Echim [i.e., Hekim], the great Lord [Sultan] hath of his owne proper and ordinary waged wyth great stipends and entertainments, whereof parte are Turkes and parte are Iewes. ${ }^{78}$

This phenomenon could be related to the influx of Jews from the Iberian peninsula,

${ }^{73}$ Uzunçarşıll, 'Ulema Sınıfına Mensup Saray Memurları', in op. cit., note 1 above, pp. 364-5.

74 'Risāle-i 'Ayni 'Alî̀, 94 in ibid., p. 364.

75 ' $1013 / 1604$ M. senesine ait küçük ruznamçe defteri', Kamil tasnifi, hususi no. 1 in'ibid., p. 365.

76 'Kānun-nāme-i Eyyūbi Efendi', 26 in ibid., p. 364.

77 Defter-i Mevājib-i ehl-i hiref for the surgeons (Jemā'àt-i jerrāhīn-i hășșa): Başvekalet Arşivi, Muvakkat No. 7362-1, v.12b, 13a-b, s.120-122; No. 7362-3, v.13b-14a, s.186-87; No. 7362-4, v. 13a-b, s.215-16; No. 7442-1, v.13a-b, s.25-26.

${ }_{78}$ Les quatre premiers livres de navigations et peregrinations orientales, de Nicolas de Nicolay, Lyons, 1568, book 3, ch. 7, 'Les médecins de Constantinople', fol. 105; The navigations, peregrinations, and voyages, made into Turkie by Nicolas de Nicolay ..., transl. T. Washington, the Younger, London, 1585, fol. 93v. 


\section{Physicians at the Ottoman Court}

via Antwerp and Venice: perhaps as many as 20,000 sought refuge over a period of time from the repercussions of the Inquisition. ${ }^{79}$ Their knowledge of European affairs made them an indispensable channel of information for the Ottoman Court, which had no embassies or representation in European states. Among those who rose to prominence in the Palace, achieving great influence over Sultans and Viziers, were physicians (plate 3). ${ }^{80}$ For example, Joseph Hamon, who came from a medical family in the service of one of the last Muslim rulers in Granada, is thought to have emigrated to Constatinople in 1493 and served as court physician under both Sultan Bayāzid II and Selim I. His 3-year-old son, whom he brought with him, was Moses Hamon, who became physician to Sultan Suleyman the Magnificient. ${ }^{81}$ Nicolas de Nicolay's description conveys his importance:

He which in the time that I was in the Levant, had first dignity and authority, among the order of Phisitions was of nation an Hebrew called Amon, of age about sixtie yeares, a personage of great authoritye, and much esteemed, as well for his goods, knowledge, and renowne, as for honour and portliness ....82

Moses Hamon is well known not only for his medical writings, but also for his valuable library. It was from his collection that the sixth-century "Anicia" Codex of Pedanius Dioscorides' De materia medica was purchased in 1569 for the Austrian Emperor for the handsome price of 100 gold ducats. ${ }^{83}$

The members of the Hamon family seem to have kept their positions through several generations, retaining their religion and using their influence to solicit the patronage of various Sultans in pulling persecuted Jewish families out of Christian countries. ${ }^{84}$ Such physicians as Salomon Ashkenazi (known as Eskinazi or Alamanoghlu), who served under three Sultans whose reigns spanned the years from 1566 to 1603, and later Daniel Fonseca, under Ahmed III, achieved distinction in the diplomatic service. ${ }^{85}$ This was not unusual. Jacob of Gaeta, known as Ya'kūb, who

\footnotetext{
${ }^{79}$ Carl Brockelmann, History of the Islamic peoples, London, 1960, pp. 316-17. For the deleterious effect of the "brain drain" from Spain in the sixteenth and seventeenth centuries, see Jose Maria LopezPiñero, Ciencia y technica en la sociedad española de los siglos XVI y XVII, Barcelona, 1979.

${ }^{80}$ Some of the physicians who came to Constantinople are included in the list given by Harry Friedenwald, 'Jews after the Expulsion', in the The Jews and medicine, Baltimore, The Johns Hopkins University Press, 1944, pp. 705-71. The dates are not, however, always reliable.

${ }^{81}$ Uriel Heyd, 'Moses Hamon, Chief Physician to Sultan Suleyman the Magnificent', Oriens, 1963, 16: $152-70$.

82 Nicolay, op. cit., note 78 above, fol. 115 .

${ }^{83}$ Busbecq, Letters, trans. Forster and Daniell, op. cit., note 9 above, vol. 1, p. 416. Also, Heyd, op. cit., note 81 above, pp. $166-8$.

${ }^{84}$ For the Hamons, see H. Dernschwam, Tagebuch einer Reise nach Konstantinopel und Kleinasien 1553/1555, ed. F. Babinger, Munich and Leipzig, 1923, p. 113; Heyd, op. cit., note 81 above, pp. 159-60, 161-2. For the intervention of the Porte to save Dona Gracia Nasi and her daughter and their property from confiscation by the Venetian authorities, see P. Wittek, "A letter from Murad III to the Doge of Venice of 1580', Bull. Sch. Orient. Afr. Stud., 1952, pp. 381-3.

85 Jewish physicians were not confined to the court. Already under Mehemmed II, the charter for his newly founded Fātih Mosque-complex had stipulated that in the hospital (dār al-shifä) "two physicians of whatever community" ( $t a ̄$ 'ifa) should serve. See Tahsin Öz, Zwei Stiftungsurkunden des Sultan Mehemed II. Fatih, Istanbul, 1935, p. 120; Heyd, op. cit., note 81 above, p. 154. This stipulation, originally written in Arabic, does not however exist in the sixteenth-century Ottoman Turkish version, see Adivar, op. cit., note 72 above, 38-39.
} 


\section{G. A. Russell}

was personal physician to Sultan Mehemmed the Conqueror (1451-81), also served as Vizier. $^{86}$

On the basis of the Court registers, one can conclude that the medical staff who were employed had arrived via a broad sprectrum of recruitment. The various channels by which they came can be summarized as follows: the devshirme, trained either at the Palace schools or in Janissary apprenticeships; outside the Palace system, either from the medical medrese, which would put them in the 'ulema cadre, or hospitals, or both; the Arab provinces of the Empire, such as Syria and Egypt; medical dynasties, Jewish or Muslim, such as the families of Hamon and Kaysūnizāde, which gained favour and served through several generations; and finally foreign physicians, most Jewish and to a lesser extent Christian. Some of the last group converted, while others retained their faith: for example the Jewish physicians, most of whom had been forced to convert to Christianity, openly embraced their own religion, which was not, as in Europe, regarded as an obstacle to their practice or treatment of non-Jewish patients. ${ }^{87}$ These physicians had trained in such established medical schools as Salamanca, Coimbra, and later Padua, and continued to publish in Hebrew or Latin. For instance, Tobias Cohen (1652-1728), who had a degree from Padua, served under four successive Sultans in both Adrianople and Constantinople. ${ }^{88}$ They represented a level of knowledge superior to that of their Muslim colleagues, who continued in the tradition of classical Graeco-Arabic medicine.

To what extent, if at all, did these foreign physicians contribute to Ottoman medicine or influence their Ottoman colleagues through the European books which they must have brought with them? We know that in the sixteenth century, under royal patronage, or the patronage of the Chief Physician, Jewish physicians prepared treatises which brought together information from Graeco-Arabic, Jewish, and European sources. For example, Moses Hamon produced a compendium on dentistry. ${ }^{89}$ There is another manual largely on compound drugs, which may also be by him, under the name of Mūsā Jālīnūs al-Isrā'ilī ("Moses, the Jewish Galen"). ${ }^{90}$ An extant treatise, also in Ottoman Turkish, on the prevention, cure, and illnesses of old age is by a Portuguese physician called Manuel Brudo. ${ }^{91}$ What is curious, however, is

\footnotetext{
${ }^{86}$ Eleazar Birnbaum, 'Hekim Ya'qub, physician to Sultan Mehemmed the Conqueror', Harofe Haivri, Historical Medicine (New York), 1954, 34: 250-222 [sic].

${ }^{87}$ Among the Marrano who escaped from the Inquisition were such distinguished physicians as Amatus Lusitanus (1511-68), whose Curationum medicinalium centuriae ran through 23 editions in Europe. He came to Salonica and reverted to Judaism. See H. Friedenwald, 'Amatus Lusitanus', Bull. Inst. Hist. Med., 1937, 5: 603-53.

${ }^{88}$ Nigel Allan, 'A Jewish physician in the seventeenth century', Med. Hist., 1984, 28: 324-8.

${ }^{89}$ A photo-copy of the manuscript in Ottoman Turkish has been published with an introduction by A. Terzioğlu: Moses Hamons Kompendium der Zahnheilkunde aus dem Angang des 16. Jahrhunderts, Munich, 1977.

${ }^{90}$ According to Adivar (op. cit., note 72 above, p. 61), this treatise (Yıldız Tıp, Ms. No. 352 and Istanbul Universitesi Kütüphanesi No. T. 7120) was written at the request of the Chief Physician Ahi Chelebi (d. 1523/24). The identity of the author is given as Moses Hamon by Terzioglu (op. cit., note 89 above, p. x), but Heyd (op. cit., note 81 above, p. 170) considers Hamon's authorship "doubtful, though not impossible".

${ }^{91}$ Uriel Heyd, 'An unknown Turkish treatise by a Jejwish physician under Suleyman the Magnificent', Eretz Israel, 1964, 7: 48-53.
} 


\section{Physicians at the Ottoman Court}

that, as far as we know, the results of possible contacts seem only to appear in the writings of Ottoman court physicans almost a century later. When European knowledge emerges in seventeenth-century Ottoman texts, it is based on earlier sources: in anatomy, for example, it shows traces of Vesalius and Valverde; ${ }^{92}$ in the "new chemical medicine", it draws largely on the late sixteenth-century Paracelsians. ${ }^{93}$ The reason why the "new" knowledge transmitted from Europe lags behind may perhaps be traced back to what was brought by the earlier Jewish physicians.

In the seventeenth century there were Ottoman Greeks who studied medicine at the University of Padua, including Panagiotis Nicoussias and his more illustrious successor Alexander Mavrocordato, known as Iskerlerzāde. Because of their knowledge of Europe and European conditions, they also rose to prominence and occupied the newly established, highly influential court position of Grand Dragoman. ${ }^{94}$ Although they became personal physicans to the Grand Viziers of the Köprülü family, they did not act to bridge the existing gap between European and Ottoman medicine. In fact, they do not even seem to have tried. Mavrocordato's dissertation on the function of the lungs in the circulation of the blood (Pneumaticum instrumentum circulandi sanguinis, Bologna, 1664), which discusses Harvey's De motu cordis, really forms part of European medical history. There is no evidence of its having been presented for royal patronage by the "Grand Dragoman", or of its having left any trace on Ottoman medicine.

\section{THE FUNCTION OF COURT PHYSICANS}

The Treasury registers provide thumbnail sketches of the careers and salaries of the court medical staff but reveal very little about their specific duties, and nothing at all about patient-doctor relationships. ${ }^{95}$ There were, however, hospitals and an infirmary in the Palace grounds. According to the plan which has survived as part of Bobovius' disclosures, the infirmary (timarhane) consisted of seven wards, a bath, a mosque for patients and staff, an office for the superintendent, and a dispensary. ${ }^{96}$ It

\footnotetext{
92 G. A. Russell, 'The owl and the pussy cat: an analysis of the process of cultural transmission in anatomical illustration', The impact of Europe on the Islamic world since the Renaissance, ed. E. İhsanoğlu (in press).

${ }^{3}$ Al-Tibb al-jadìd al-kimīyāì alladhī ikhtarā'ahū Barākilsūs (The new chemical medicine invented by Paracelsus) constitutes the fourth and final part of Ibn Sallum's work, entitled Ghāyat al-itqān fi tadbïr badan al-insän, London, Wellcome Institute, Ms. Or. 24, copied AH 1050/1640 AD. A Turkish translation of this work is preserved in various libraries, e.g., London Wellcome Institute, Ms. Turkish Med. 3. It had a widespread influence on subsequent physicians in the eighteenth century. Not all copies, however, contained the treatise on the "New Chemical Medicine", which also exists separately. It is significant that, according to Adivar, it was translated from Latin into Arabic with the help of someone by the name of Suleyman b. Ibrahim (Solomon b. Abraham): op. cit., note 72 above pp. 115. For a selective comparison with a number of sixteenth-century sources, see H. Isaacs, 'European influences in Islamic medicine', in Mashriq (Proceedings of the Eastern Mediterranean Seminar, University of Manchester, 1977-78), pp. $26-9$. Ibn Sallūm also showed, however, acquaintance with such early seventeenth-century Paracelsians as Sennert and Kroll, which he again could have acquired via the mediation of the Jewish court physicians.

94 Adivar, op. cit., note 72 above, pp. 118-19.

95 Miller, Palace School, op. cit., note 25 above, p. 168; Panzer, op. cit., note 6 above, p. 84.

96 For the attraction of the infirmary for the pages, see J.-B. Tavernier (1605-89) in his Nouvelle relation de l'interieur du Serrail du Grand Seigneur, Paris, 1675; A new relation of the inner part of the Grand Seigneur's Seraglio, London, 1677, p. 22. He describes how the pages tried to get into the infirmary on some pretext or other: "They continuie there for a space of ten or twelve daies, and are diverted, according to
} 


\section{G. A. Russell}

seems to have served almost exclusively the Palace School, coming under the jurisdiction of the Bash Lala. As head of the Palace School, he was also the head of the infirmary. A larger hospital in the First Court served the Palace. According to foreign accounts, the numerous orderlies, litter bearers, and the guards of the outer gate, who received the incoming patients and assigned beds to them, were all white eunuchs. From among the medical staff, which was made up of court physicans and surgeons, two senior physicians were required to be continuously on duty. ${ }^{97}$

The hospitals were described as serving to isolate the sick:

When any ordinary person falls sick in the Seraglio, he is immediately carried from his chamber in a cart which is covered with cloath, and drawn with hands, and is put in the aforesaid Hospital, or Lazaretta, belonging to the house onely, where he is lookt unto after the Turkish fashion, and kept so closely that none may come to speech of him (except the Physician, or apothecary) but with great difficulty; and growing well again, he must be carried back in the same manner to his chamber where he was at the first. ${ }^{98}$

In fact, according to Thevenot's report in his Voyage au Levant, everyone had to step aside to make way for the patient-bearing cart to which he refers as "un petit chariot fermé", including the "Grand Seignor" if he should encounter it (plate 4). ${ }^{99}$

The Palace surgeon's routine duties included the physical examination of the eunuchs when they first entered Palace service (they were never castrated at the Palace but purchased as eunuchs). ${ }^{100} \mathrm{He}$ also examined the novices (ajemi oghlans) at their selection and circumcised pages, palace staff, and most important all, the young princes: splendid pageantry accompanied the ceremony, which was depicted in the miniatures of contemporary court painters. ${ }^{101}$

From the time of Suleyman the Magnificent, court physicians and surgeons, including the Chief Physician, accompanied the Sultan on military campaigns. ${ }^{102}$

their mode, with a wretched kind of musick, which begins betimes in the morning and holds till night. The permission they have there to drink wine, which they never have elsewhere, is of greater inducement for their coming in thither than the musick." It is also reported that skins of wine were smuggled in to make the eunuchs lax in their duties, "so that certain vicious practices impossible in the Seraglio were indulged in with impunity" (Panzer, op. cit., note 6 above, p. 85). The wine was purchased by the pages surreptitiously from the gardeners. Malmsey and muscatel were much sought-after at the French embassy, by emissaries from the Porte or the Palace. (Miller, op. cit., note 2 above, p. 200).

${ }^{97}$ Rycaut listed among the Privy Chamber positions, that of Berber-bashi or Chief Barber, as distinct it seems from the surgeon: op. cit., note 10 above, $28-9$.

${ }^{98}$ Withers, op. cit., note 27 above, pp. 141-2. Attendants of the hospital for sick pages were novices (ajemi oghlans), from the devshirme: Rycaut, op. cit., note 10 above, $x, 41$.

99 Jean de Thevenot, Voyage au Levant, 1687, p. 58.

100 Uzunçarş1l, op. cit., note 1 above, p. 368; Panzer, op. cit., note 6 above, p. 149. Their duties-could be surmised also from the nature of surgery in Islamic manuals such as the illustrated Jerrähiye-i Ilhäniya by Sharaf al-Dīn Sabunjuoghlu, based on Abu'l Kāsim al-Zahrāwī (Albucasis). See P. Huard and M. D. Grmek, Le premier manuscript chirurgical turc, rédigé par Charaf ed-Din (1465), Paris, R. Dacosta, 1960.

${ }^{101}$ See, for example, the Shehnäme-i Lokman. Topkapı Saray, Hazine, 1524 and 1588, made for Murād III. Also Rycaut, op. cit., note 10 above, xxii, 157.

102 From among the Court Hasssa surgeons, the best were appointed as Chief Surgeon to the army; see Süheyl Ünver, 'Süleymaniye Darüş̧ifasında tahsil eden cerrahlardan birine ait vesika', Türk Tip Tarihi Arşivi, 1942, pp. 19-20 in Gürkan, op. cit., note 69 above, p. 260 . Although non-Muslims could not serve in the Janissary corps, there were no restrictions with regard to taking Jewish physicians and surgeons, see Heyd, op. cit., note 81 above, pp. 155-6. 


\section{Physicians at the Ottoman Court}

Their duties included embalming the body of the Sultan if he died away from the capital, as Suleyman did at the siege of Vienna. ${ }^{103}$

\section{THE CHIEF PHYSICIAN}

At the head of the court physicians was the Chief Physician, Hekimbashi (or ser etibbā'-i hāsșa). As a court physician, he belonged to the Privy Chamber, the most prestigious of the court chambers in the service of the Sultan. As such, he came under the jurisdiction of the Bash Lala, the Royal Tutor and Head of the Palace School. ${ }^{104}$ Accordingly, his residence was in the Bash Lala Kulesi, or Tower, which dates back to Sultan Mehemmed the Conqueror's time. It has been described as

a strange building, rather like a fortress, with walls nearly two metres thick and few windows, lofty though it is, and these are barred except for a chaplet of small casements at the top, where the physician would have had a private chamber. Below is a store for drugs and medicaments which, with its sombre atmosphere, when the fire was lit, must have looked like a true alchemist's den. ${ }^{105}$

The fortress-like appearance of the Tower could be related to the fact that its "alchemist's den" contained drugs rarer than those kept in the Royal Store. These would have included antidotes to poisoning, which was a real danger. ${ }^{106}$ There is, for example, evidence of a court physician by the name of Ammonius-perhaps a member of the Hamon family - writing in 1556-60 to seek advice on antidotes for use in his practice from Amatus Lusitanus, a well-known Jewish physician who had found refuge in Salonika from religious and professional persecution in the West. ${ }^{107}$ Among the antidotes was the much sought-after terra lemnia, the brown, red, or (even rarer) white clay which was procured only once a year, on 6 August, from the island of Lemnos. In addition to being efficacious against poisoning, it was considered to have aphrodisiac properties. ${ }^{108}$

It was in the Tower that, under the supervision of the Chief Physician, prescriptions were made up by an apothecary. They were put in special containers and sealed in the presence of the Chief Physician and the Bash Lala, to be administered to the royal patients as required. ${ }^{109}$ In addition to medicines, it became customary for the Chief

103 Süheyl Ünver, 'Kanuni Sultan Süleyman'ın son Avusturya seferinde hastalığı ve ölümü, cenazesi ve defni', in Kanuniye Armă̆an, Ankara, 1970, pp. 301-6.

104 M. Tayyar Gökbilgin, s.v. "Hekimbash1,” Encyclopaedia of Islam, 2nd ed., Leiden, 1965, pp. 339-40.

105 Godfrey Goodwin, A history of Ottoman architecture, London, Thames \& Hudson, 1971, p. 135.

106 Izzet, 'Topkapı Sarayında Ilk Eczahane: Hekimbaşı Odası, Baş-lala Kulesi', Farmakolog (Haziran), 1932, 2(6): 457-60, and ibid. (Ağustos), no. 8: 493-4; Gibb and Bowen, op. cit., note 13 above, vol. 1, p. 347.

107 According to Heyd (op. cit., note 81 above, p. 170), “Ammonius” could be Hamon's son Joseph who, after his father's death, served as court physician.

108 In the correspondence (which was drawn to my attention by Vivian Nutton) of Crato von Crafftheim (1519-95), Consiliorum et epistolarum medicinalium, liber $V$, Hanau, 1619, pp. 364-70, we have a description of medicine at the Ottoman court in which Brudus Lusitanus is praised as the prince of Ottoman physicians, and as the keeper of the Sultan's perfumes as well as of the terra lemnia. There is a Latin publication under Lusitanus' name, Liber de ratione victus in singulis febribus, Secundum Hippocratem, Venice, 1544; its 1559 edition has the added words, in genere et sigillatim, Libri iii.

109 A manuscript containing recipes of electuaries prepared in the "confectionary" department (Halvahāne) of the Palace between 1604 and 1708 includes one called $M \bar{a}$ 'jūn-u 'Ayārij-i Jālinūus: see T. Baytop, Türk Eczacılık Tarihi, 1958, pp. 207-8. 


\section{G. A. Russell}

Physician to prepare electuaries for particular occasions. For example, on the eve of the Solar New Year (21 March) or Nev-rüz, he would formally present to the Sultan, members of his household, and palace and government officials, a red and fragrant $m \bar{a}$ 'jün or electuary in special porcelain cups. Called Nevrüziyya, it was prepared from a compound of amber, opium, and various plants. ${ }^{110}$ In return, the Sultan would reward the Chief Physician with a sable cloak. ${ }^{111}$

Chief Physicians also had the duty of preparing medical texts on the order of the Sultan for which they could also, according to custom, receive fur-lined cloaks (hil'at) as a mark of royal patronage. Under Mehemmed IV (1648-87) the Chief Physician, Șālị̣ ibn Naşr-Allāh al-Ḥalabī Ibn Sallūm (d. 1670) was similarly rewarded for his major medical work, the earliest attempt to describe the new chemical medicine (al-tibb al-jadid al-kimìyā'i) with reference to the works of such Paracelsians as Jacob Wecker (d. 1586), Oswald Croll (d. 1609), and Daniel Sennert (d. 1637). ${ }^{112}$

The origin of the custom of presentation of the Nevruziyya is attributed to Hayātī-zāde Muștafā Feyzī (d. 1691), a Jewish convert, who followed Ibn Sallum as Chief Physician under Mehemmed IV, and who is said to have acted as interpreter during the interrogation of the "messiah", Shabbetay Sevi. ${ }^{113}$

The Chief Physician was, of course, responsible for the Sultan's health, on which his position depended. If the Sultan fell ill, and he did not succeed in curing him, he could be dismissed. If the illness of the Sultan or another member of the royal household was prolonged without a successful cure, then an outside or foreign physician could be brought in for a joint consultation which was not always free of non-medical machinations. ${ }^{114}$

The successful treatment of a patient usually meant not only rich gifts but also promotion. For instance, when the condition of Sultan Suleymen, who suffered from nikris (perhaps gout), grew worse under the treatment of his own physician Moses Hamon, another physician was called in. He was Kaysūnī-zāde Mạ̣mūd, who had already proved himself by curing one of the Sultan's sons of a dangerous illness. He came from an Egyptian family of distinguished physicians who had served at the Ottoman Court at the highest levels. ${ }^{115}$ In the presence of the Sultan, the Chief

\footnotetext{
${ }^{110}$ It is mentioned by Tavernier (op. cit., note 96 above) as being prepared in the "confectionary" department.

${ }_{11}$ Uzunçaşll, op. cit., note 1 above, pp. 365-7.

112 Adivar, op. cit., note 72 above, pp. 114-16; Salman Kataye, Les manuscripts médicaux et pharmaceutiques dans les bibliothèques publiques d'Alep (Makhtutat al-tibb wa al-saydalah fi al-makhtabat al-'ammah bi-Halab), Aleppo, 1976, pp. 213-28, esp. p. 227. See also Paul Richter, 'Paracelsus im Lichte des Orient', Arch. Gesch. Naturwiss. Tech., 1913, pp. 294-304.

113 Izzet, op. cit., note 106 above, p. 33; Adıvar, op. cit., note 72 above, pp. 116-18; A. Galante, Médecins juifs, Istanbul, 1938, pp. 13-14; Nouveaux documents sur Sabbetai Sevi, Istanbul, 1935, pp. 95, 106. Bursalı Tahir, Osmanli Mü'ellifleri, Istanbul, 1928, iii, 232.

114 Mehemmed II's death in 1481 has been attributed to a physician brought in from outside, who himself died four days later, possibly by an overdose of opium forced on him by the sultan's son and successor, Bayāzid II. F. Babinger, Mehmed the Conqueror and his time, transl. R. Manheim and W. C. Hickman, Princeton University Press, 1978, pp. 403-4. Bayāzid was also implicated in the poisoning of his brother Prince Jem, in exile in the hands of the Vatican.

115 Uzunçarşılı, op. cit., note 1 above, p. 389; Heyd, op. cit., note 81 above, p. 162. B. Lewis, 'The privilege granted by Mehmed II to his physician', Bull. Sch. Orient. Afr. Stud., 1952, $14: 552$.
} 


\section{Physicians at the Ottoman Court}

Physician, Mehemmed Chelebi, and court physicians, a disputation was held, followed by a second in the presence of the Chief Tutor. Kaysūni-zāde seems to have shown that his colleague's treatment by massaging the Sultan's leg with an opium ointment might provide temporary relief but would in the long run seriously impair his health. The royal patient was transferred to him. He was rewarded for his successful treatment by being appointed to the court where he subsequently served as the Chief Physician until Sultan Suleyman's death. ${ }^{116}$

With the Sultan's permission, the Chief Physician could also be admitted into the Harem in order to treat the women. ${ }^{117}$ According to a contemporary account,

he sees none but the black eunuchs (all the other women being retired into some withdrawing rooms) who bring him into the sick woman's chamber, and she being closely covered from head to foot with quilts, and blankets, holdeth out her arm only, so as the doctor may touch her pulse, who, when he hath given order what shall be done, both for her diet and medicines, goes his way immediately by the same way that he came. ${ }^{118}$

\section{The examination seems to have been even more restricted}

if she, which is sick, be the Queen or one of the Sultanaes (with whom the Grand Signor hath layen) then her arm and hand, which she holdeth out of the bed for the physician to feel her pulse, is covered with a fine peece of white silk, or Taffeta sarcenet. For her flesh may not be seen or touched bare; neither may the doctor say anything in her hearing, but being gone out of her chamber, prescribeth what medicine he thinks fit; which for the most part (according to the knowledge and common custom of the Turks) is some kind of loosening and refreshing sherbert. For they seldom use any other physick, nor do I hold their skill sufficient to prepare medicines for every malady.

If, however, a surgeon were needed, although women who were not the Sultan's favourites could be treated, those who were, "either for their person, or for some peculiar and extraordinary vertues", had no choice but "to suffer without any scruple. For there is no remedy to conceal her skin and flesh from him [the surgeon]". 119

The Chief Physician or any of the other court physicians could also be sent by the order of the Sultan to treat patients outside the palace. ${ }^{120}$ They were usually high-ranking officers, such as the Vizier and his household, from whom payment as

116 The Register of Court officials for February 1548 to August 1549 lists 17 Muslim physicians, with Kaysūnī-zāde as Chief Physician, together with 13-14 Jewish physicians; see Başbakanlik Arşivi, Maliye Defterleri, in Heyd, op. cit., note 81 above, p. 158. Members of the Kaysūni-zạde family who became Chief Physicians between 1511 and 1611 are listed in the 'Hekimbaşlar Cedveli' by Izzet, op. cit., note 106 above, p. 33.

117 This was under exceptional circumstances, and with the permission of the Sultan or the Chief Black Eunuch. He would be entered in the visitors' record book: Ottaviano Bon, Il Serraglio del gransignore, 1608 , ed. G. Berchet, Venice, 1865, in Miller, op. cit., note 2 above, p. 10.

118 Withers, op. cit., note 27 above, p. 110.

119 Ibid.

120 The households of provincial high officials or princes, modelled on that of the Palace, included physicians with apprentices. For example, before his accession to the throne, while serving as a Sanjak Beg, Prince Suleyman had two physicians, one of whom was Jewish, as well as a woman physician (Kari hekime or hekime hātun). Their daily pay reflected their status: Mevlāna Ramazan, 40 akchas; Sinan, is; the woman, 2; and the apprentices, 2 akchas (Topkapı Sarayı, Ar. D. Nos. 8030 and 10052): Çağatay Uluçay, 


\section{G. A. Russell}

well as rich gifts of gratitude were received. ${ }^{121}$ For example, Andres Laguna, the controversial Spanish author of the Viaje de Turquia, who was taken prisoner in 1552, became a slave of Sinan Pasha, Admiral of the Ottoman Fleet and Grand Vizier, Rustem Pasha's brother. As a physician, he seems to have insinuated himself into the household. Having successfully treated the Sultan's daughter, who was the wife of the Grand Vizier, he volunteered to cure the Admiral himself of dropsy. According to his own account, his advice of immediate surgery was taken in spite of the opposition of the Sultan's physician (el proto medico principal). The operation was successfully carried out, not by the Spaniard but by a Jewish surgeon from Naples. The patient's death shortly after the surgery does not seem to have tarnished his influence in the least. At the prospect, however, of being sent as a physician to the Court by the Sultan's daughter, he seems to have escaped to Spain. ${ }^{122}$

If the Sultan was deposed or executed (which was always by strangulation, using a bow string in order not to shed the blood of a member of the House of Othman), the Chief Physician kept his post because the Sultan's death was not his responsibility. On the succession of a new Sultan, he could be dismissed or re-appointed. ${ }^{123}$ Although he could be victimized by the intrigue of envious colleagues, on the whole his position was not too precarious, at least financially, because on retirement he continued to receive his daily stipend. His salary was supplemented not only by the official gifts of summer and winter garments or more specifically "rolls of cloth" and fur, but by the grants in the form of fiefs from around Adrianople (Edirne), Tekirdag, and Gallipoli (Gelibolu). ${ }^{124}$ The high esteem and comfort he enjoyed in the seventeenth century is reflected in Evliya Chelebi's report that the Chief Physician had 100 servants. ${ }^{125}$ Together with the highest officials who had passed through all the levels of the medrese education to earn the title of mevläna, he was permitted to wear fur cloaks like the Viziers and admitted to the ceremony at which the new sovereign was accorded allegiance (bey'at), and again when this ceremony was repeated during the

'Kānuni Sultan Süleyman ve Ailesi ile İlgili Bazi Notlar ve Vesikalar', Kânuni Armağanı, Ankara, 1970, pp. 237-57, esp. pp. 245,248 . It is possible that the female physician was also Jewish. At the Palace, among the women who variously served the ladies of the Imperial Harem in their contacts with the outside world, were Jewish women with medical as well as diplomatic skills. According to S. Skilliter ('Three letters from Safiye to Elizabeth I', in Documents from Islamic chanceries, ed. S. M. Stern, Oxford, 1965, p. 144), such women had "the title of Kira". As the word kira appears in foreign documents, it could be a corruption of the Ottoman term karl, indicating not only "a woman", but a skilled woman who could read and write and conduct correspondence in a foreign language. For example, there is a letter (ibid., pp. 140-2) from the mother of Sultan Mehemmed III to Queen Elizabeth I, written in Italian by her kira Esperanza Malchi, dated 1599. Also see, J. H. Mordtmann, 'Die jüdischen Kira im Serai der Sultane', Mitt. des Seminars für orientalische Sprachen, Westasiatische Studien, 1929, 32: 1-38.

121 Uzunçarşılı, op. cit., note 1 above, p. 366.

122 Heyd, op. cit., note 81 above, pp. 163-4; Marcel Bataillon, 'Nouvelles recherches sur le viaje de Turquia', Romance Philol., 1951-2, 5: 77-97. See Andrés de Laguna, identified as a physician from Segovia, Aventura di una schiavo dei Turchi, chs. v-xi, esp. 'Medici e medicioni', pp. 125-67, Milan, 1983. I owe this reference to Michael Rogers.

${ }^{123}$ Uzunçarşlil, op. cit., note 1 above, p. 367.

124 M. Z. Pakalın, Tarih Deyimleri ve Terimleri Sözlüğü, 2 vols., Istanbul, 1951, pp. $795-6$.

125 Chelebi, op. cit., note 28 above, vol. 1, p. 530. In the sixteenth century Chief Physicians received 80 akchas per day, whereas the Janissary Commander-in-Chief got 100; for grants, see Uluçay, op. cit., note 120 above, pp. 240, 242. 


\section{Physicians at the Ottoman Court}

two religious festivals. ${ }^{126}$ As head of the court physicians, who were carefully organized in ranks of seniority, and as private consultant to the Sultan, the Chief Physician, would, on formal occasions, be elaborately addressed as "the Galen and Hippocrates [in this order] of the age". ${ }^{127}$ This honorific title was also used in the official address of such high-ranking physicians as Moses Hamon. ${ }^{128}$

The Chief Physician also had administrative duties. From the sixteenth century onwards, he supervised the physicians, surgeons, oculists, and the whole of the medical staff, including the astrologers, at the Palace. He was responsible for their appointments, transfers, promotions, and dismissals by submitting his proposals to the Imperial Council. In fact, he was in charge of the medical practitioners in the whole of the Empire, Muslim and non-Muslim, determining appointments to hospitals, such as that of Bayāzid II in Bursa and Mehemmed II in Istanbul, as well as those to other palaces, such as that of Ibrahim Pasha and Galatasaray. ${ }^{129}$

The Chief Physician administered the medical profession through the guilds. Emerging at the end of the fifteenth or the beginning of the sixteenth century, the guilds had developed into a comprehensive system linking the government and the urban population. A characteristic and significant feature of the Ottoman guilds, in contrast to those of Europe, was the fact that they were also controlled and maintained from above, serving the purposes of the state. What made this control possible was their geographical concentration in one specific quarter or street, as well as their confinement to members of the same religious or ethnic community. ${ }^{130}$

Furthermore, the Chief Physician had the daunting responsibility of protecting the Sultan's subjects from a proliferation of medical quacks. Documents from the sixteenth and seventeenth centuries show, for example, that edicts were sent to the $K \bar{a} d \bar{l}$ of Istanbul to put a stop to unlicensed apothecaries and practitioners who posed as physicians, surgeons, and oculists, "giving Muslims deadly syrups" ( $k \bar{a}$ 'til sherbetler) and "poisonous purgatives" (zehirnāk mushiller); to demand that unless they acquired a licence and demonstrated their skill and expertise by a proper examination in the presence of the Chief Physician, they were not to practise or administer drugs. If they persisted in defying this edict, their names and identity were to be established and proper procedures would be taken against them. ${ }^{131}$

These edicts were not addressed merely to medical quacks, but to foreigners who had come from France and England, practising chemical medicine, "whose adverse effects exceed any benefit to be had". A case reported in 1702 has all the hallmarks of the "chymical and galenical controversy". A young man from the "ulemā class died within 24 hours of being treated by a practitioner of the chemical medicine ( $t i b b-i$ kimiy $\left.\bar{a}^{\prime} i\right)$. The physician responsible, a convert this time, was brought before the Chief Physician and forced to take the fatal medicine which he had administered to

126 Gibb and Bowen, op. cit., note 13 above, vol 1, pp. 90-1.

${ }^{127}$ Feridun Beğ, Münşe 'àt-l Selātin, vol. 1, Istanbul, 1847, p. 12.

${ }^{128}$ Lewis, op. cit., note 115 above, p. 552.

129 Uzunçarşili, op. cit., note 1 above, p. 367.

130 A. Refik, Hicri Onuncu Astrda Istanbul Hayatl, Istanbul, 1933, pp. 62-4, documents dated AH 981/1573 AD, 985/1579, 984/1581.

${ }^{131}$ For the text, see M. Kohbach, 'Europaische Ärzte im osmanischen Reich am Beginn des 18. Jahrhunderts-der Fall Shinasi', Sudhoffs Arch., 1980, 64; pp. 80-1. 


\section{G. A. Russell}

the patient. Even though the physician manifested no immediate ill-effects, he was barred from practising in Istanbul, Edirne or other "Islamic" cities. ${ }^{132}$ Interestingly, the Chief Physician, Nuh b. 'Abd al-Mennāb, who had previously served as Chief Surgeon, was of Greek or Italian origin, having been taken during the capture of Rethymno, Crete, in $1646 .{ }^{133}$

If such documents indicate an attempt to standardize the medical profession, then whether this effort was confined to Istanbul or carried out in the rest of the Empire remains to be investigated. What clearly emerges from the various sources is that the Chief Physician was not only responsible for the well-being of his royal patients, and the medical profession at the Court; he was, at least until the mid-seventeenth century, the administrator, par excellence, of the Ottoman health services. From the seventeenth century onwards, however, his central authority and the importance of his post seem gradually to have diminished.

\section{CONCLUSION}

The Ottoman Court was dramatically different from its contemporaries. Focusing on its extraordinary features, Europeans saw in its organization a mirror of Ottoman society. There was no middle class, no aristocracy; instead, there seemed to be preferment without hereditary privilege and family connections, in stark contrast to the west. The devshirme and the Palace School seemed to them the key to the system of Ottoman power, in which the Sultan was served by loyal servants whom he could "raise without envy and destroy without danger", but that offered boundless opportunity for the worthy. This highly romanticized view represented only one side of the coin. Distinguished Ottoman products of the system also saw corruption in high places and the elevation of the unworthy.

A reconstruction of the nature of the Ottoman system from its own archival sources shows the medical profession to have been part of an intricate bureaucracy. It was centred at the Court, occupying a specific place in the hierarchy of the Court organization. It was fed by diverse channels, from within as well as outside the system of Palace education. It encompassed the devshirme, the Ottoman as well as the foreigner, whether "turned Turk" or not. As part of the Imperial household, its members were completely dependent on the Sultan, rewarded for the smallest service, whether the presentation of an electuary or the cure of a royal patient, and punished for any abitrary action with ruthless disregard for their ability or achievement.

With a method of selection largely based on physiognomy, emphasizing the Aristotelian mean, and a training which ideally might have been based on "merit",

\footnotetext{
132 Meḥmed Rāşid, Tärih, II, 321-25, in ibid., p. 82, note 13. On the interpretation of "the patronymics of converts" as a criterion for indicating whether the person was Muslim-born or recruited through the devshirme or otherwise, see V. L. Ménage, 'Seven Ottoman documents in the reign of Mehemmed II' in Stern (ed.), op. cit., note 120 above, esp. pp. 112-18.

${ }^{133}$ G. Baer, 'Guilds in Middle Eastern history' in M. A. Cook (ed.), Studies in the economic history of the Middle East, London, Oxford University Press, 1970, pp. 11-30; also idem, 'Monopolies and restrictive practices of Turkish guilds', J. econ. soc. Hist. Orient, 1970, 13: 146-65, esp. p. 153, 156. Baer's study is based on the fermäns (edicts) published by Osman Nuri, Mejelle-i Umur-u Belediye, vol. 1, Istanbul, 1922; Ahmet Refik, Onuncu Astrda Istanbul Hayatı, Istanbul, 1933; and idem, Onbirinci Astrda Istanbul Hayat , Istanbul, 1931.
} 


\section{Physicians at the Ottoman Court}

but which in reality would have been subject to the Machiavellian machinations of ambitious men desirous of posts and preferment, the result was not a series of brilliant minds. There were indeed men with military and administrative ingenuity to cope with the problems of an enormously complex empire. If the much-praised Palace system succeeded in producing distinguished men in a wide range of areas, it also seems to have stifled any intellectual curiosity with subservience and the discipline of obedience.

Without exception, there is no evidence of an iconoclastic approach or a novel discovery by the Sultan's $\mathrm{kul}$. While Europe was experiencing a period of immense scientific creativity and intellectual ferment, the Court system displayed a hierarchical authority and conformity that may have guaranteed social stability within the Empire, but also produced an immunity to the influence of new ideas.

This is clearly seen at the time of the influx of well-trained, Jewish physicians educated in the best European medical universities such as that in Padua. The nature of the Court system and the background of the Ottoman physicians was such that this "new blood" was unable to stimulate any immediate changes or directly influence the state of medical knowledge. A list of books on loan to the Chief Physician for the duration of his term of office shows that medical education remained within the range of classic Islamic texts, from Yūhannā ibn Sarābiyūn's Kunnāsh to Ibn Sinā's $Q \bar{a}$ nūn. ${ }^{134}$ Not even Ibn al-Nafis's deviation from the Galenic theory of the movement of blood was understood. Though hospitals were endowed, a special medical medrese was built, and medical texts were written under imperial patronage, there was more concern with preferment than the state of medicine. In fact, medicine, the "queen of sciences" of the classical Islamic period, become a "servant-slave" of administration. The ideal was no longer the physician-philosopher, as epitomized by Avicenna (d. 1037), or the physician-theologian-jurist, as exemplified by Averroes (d. 1198) and Ibn al-Nafis (d. 1288). The Ottoman model, in perfect conformity with the aims of the Palace School system, was the Chief Physician as the head civil servant of the Empire's medical profession. The title, "Galen of his time" went with his rank, like the fur-lined cloak conferred on him by the Sultan on ceremonial occasions. In his hands, the medical profession, centred at the Court, became as highly regulated as every other aspect of Ottoman life. Totally identified with the State bureaucratic ideal, it was incapable of intellectual curiosity and remained impervious to outside influence. ${ }^{135}$

\footnotetext{
${ }^{134}$ See note 62 above.

135 For an analysis of the Europeanization of the Ottoman medical profession, see Russell, op. cit., note 92 above.
} 